\title{
AKIBAT HUKUM KELALAIAN KREDITUR DALAM MELAKUKAN ROYA ATAS JAMINAN FIDUSIA
}

\author{
Ninik Meiyudianti \\ Magister Kenotariatan, Fakultas Hukum, Universitas Narotama Surabaya \\ Email : ninik.jurnal2018@gmail.com
}

\begin{abstract}
Obligation of creditor in making report for nullification of debt in fiduciary registration office to delete the record of fiduciary object is known as liability omission (Roya). Liability omission can be done when debtor paying off all debts that is possessed to the creditor. When liability omission (roya) is not conducted by the creditor after debtor pay off all the debt, it certainly harms the debtor since he/she as debtor is not able to use the fiduciary object to make new credit agreement with other parties.

The present research aims to elaborate and examine further about the obligation of creditor in performing liability omission toward the fiduciary object when the debtor paying off all the debts. Moreover, the present study tries to elaborate further about accountability of creditor regarding negligence in performing liability omission toward fiduciary object that has been paid off.

The method used in the present study is a normative legal research, namely legal research which is conducted by examining the library materials or secondary law while in finding and collecting the data is done by two approaches, namely the law and conceptual approaches.

The present study shows that deletion record of fiduciary object based on paying off of debts by the debtor shall be performed by the creditor. When creditor neglects in performing this act within fourteen days (14) after the repayment of debt, it can be justified as infringement of law. Moreover, creditor shall responsible to pay all losses that is experienced by the debtor.
\end{abstract}

Keywords: Deletion of Fiduciary Object, Infringement of law, Accountability

\begin{abstract}
ABSTRAK
Kewajiban kreditur melakukan laporan atas hapusnya hutang kepada kantor pendaftaran fidusia untuk dilakukan pencoretan pencatatan jaminan fidusia dikenal dengan sebutan roya. Roya dilakukan setelah debitur melunasi seluruh hutang yang dimilikinya kepada kreditur. Kewajiban melakukan roya tersebut apabila tidak dilakukan oleh kreditur tentunya akan merugikan debitur karena debitur tidak dapat menjadikan benda yang dimilikinya tersebut sebagai obyek jaminan fidusia pada saat debitur akan melakukan perjanjian kredit dengan pihak lain setelah dilunasinya hutang yang lama.

Penulis dalam penelitian ini ingin menelaah dan menganalisa lebih lanjut tentang kewajiban kreditur atas jaminan fidusia yang telah dilunasi debitur dan tanggung gugat kreditur atas kelalaian melakukan roya pada jaminan fidusia yang telah lunas.
\end{abstract}


Metode penelitian yang digunakan adalah penelitian hukum normatif, yaitu penelitian hukum yang dilakukan dengan cara meneliti bahan pustaka atau bahan hukum sekunder sedangkan pendekatan masalah dilakukan dengan menggunakan pendekatan undangundang dan pendekatan konseptual.

Pencoretan pencatatan Jaminan Fidusia setelah hapusnya Jaminan Fidusia karena adanya pelunasan hutang oleh debitur menjadi kewajiban dari kreditur. Kreditur yang karena kelalaiannya tidak melakukan pencoretan pencatatan Jaminan Fidusia dalam waktu 14 (empat belas) haris setelah adanya pelunasan hutang dari debitur dapat dikualifikasikan melakukan perbuatan melawan hukum dan bertanggung gugat untuk mengganti kerugian yang dialami oleh debitur.

Kata Kunci : Pencoretan Jaminan, Perbuatan Melawan Hukum, Tanggung Gugat

\section{PENDAHULUAN}

II.

\section{A. Latar Belakang \\ III.}

IV. Salah satu lembaga jaminan yang dikenal dalam sistem hukum jaminan di Indonesia adalah lembaga jaminan fidusia. Fidusia yang berarti penyerahan hak milik atas dasar kepercayaan memberikan kedudukan kepada debitur untuk tetap menguasai barang jaminan, walaupun hanya sebagai peminjam pakai untuk sementara waktu atau tidak lagi sebagai pemilik.

V. Di Indonesia, lembaga jaminan fidusia diatur melalui peraturan perundang-undangan yaitu UndangUndang Nomor 42 Tahun 1999 Tentang Jaminan Fidusia (selanjutnya ditulis UU Jaminan Fidusia), dengan berlakunya UU Jaminan Fidusia, pengikatan jaminan hutang yang dilakukan melalui jaminan fidusia wajib mematuhi ketentuan undang-undangnya. Undangundang ini dibentuk karena terdapat beberapa pertimbangan yaitu pertama bahwa kebutuhan yang sangat besar dan terus meningkat bagi dunia usaha atas tersedianya dana, dimana perlu diimbangi dengan adanya ketentuan hukum yang jelas dan lengkap yang mengatur lembaga jaminan, kedua jaminan fidusia sebagai salah satu bentuk lembaga jaminan sampai saat ini masih didasarkan pada yurisprudensi dan belum diatur dalam peraturan perundang-undangan secara lengkap dan komprehensif dan ketiga untuk memenuhi kebutuhan hukum yang dapat lebih memacu pembangunan nasional dan untuk menjamin kepastian hukum serta mampu memberikan perlindungan hukum bagi pihak yang berkepentingan, maka perlu dibentuk ketentuan yang lengkap mengenai jaminan fidusia dan jaminan tersebut perlu didaftarkan pada kantor pendaftaran fidusia. Berdasarkan ketiga pertimbangan tersebut maka dipandang perlu untuk membentuk UU Jaminan Fidusia.

VI. Jaminan fidusia adalah hak jaminan atas benda yang bergerak baik yang berwujud maupun yang tidak berwujud dan benda tidak bergerak khususnya bangunan yang tidak dapat dibebani hak tanggungan sebagaimana dimaksud dalam Undang-Undang Nomor 4 Tahun 1996 tentang Hak Tanggungan yang tetap berada dalam penguasaan pemberi fidusia, sebagai agunan bagi pelunasan utang tertentu, yang memberikan kedudukan diutamakan kepada pemberi fidusia terhadap kreditor lainnya. 
VII. Pengertian tentang jaminan fidusia terdapat di Pasal 1 angka (2) Undang- Undang Fidusia yang menyebutkan bahwa Jaminan fidusia adalah hak jaminan atas benda yang bergerak baik yang berwujud maupun yang tidak berwujud dan benda tidak bergerak khususnya bangunan yang tidak dapat dibebani hak tanggungan sebagaimana dimaksud dalam Undang-Undang Nomor 4 Tahun 1996 tentang Hak Tanggungan yang tetap berada dalam penguasaan pemberi fidusia, sebagai agunan bagi pelunasan utang tertentu, yang memberikan kedudukan diutamakan kepada pemberi fidusia terhadap kreditor lainnya.

VIII. Suatu perubahan yang cukup mendasar dari perkembangan jaminan fidusia adalah mengenai pendaftaran. Sebelum terbitnya UU Jaminan Fidusia, masalah pendaftaran jaminan fidusia bukanlah menjadi suatu kewajiban, tetapi setelah keluarnya UU Jaminan Fidusia masalah pendaftran jaminan fidusia semakin krusial. Pendaftaran tersebut memiliki arti yuridis sebagai suatu rangkaian yang tidak terpisah dari proses terjadinya perjanjian jaminan fidusia. Selain itu, pendaftaran jaminan fidusia merupakan perwujudan dari asas publisitas dan kepastian hukum. ${ }^{1}$

IX. UU Jaminan Fidusia mengatur tentang kewajiban pendaftaran jaminan fidusia agar memberikan kepastian hukum kepada para pihak yang berkepentingan dan pendaftaran jaminan fidusia ini memberikan hak yang didahulukan (preference) kepada penerima fidusia terhadap kreditor lain. Pendaftaran jaminan fidusia diatur pada Pasal $11 \mathrm{UU}$ Jaminan Fidusia yaitu : (1) Benda yang

\section{H. Tan Kamelo, Hukum Jaminan Fidusia} Suatu Kebutuhan Yang Didambakan, Alumni, Bandung, 2006, hal. 213 dibebani dengan jaminan fidusia wajib didaftarkan; (2) Dalam hal benda yang dibebani dengan Jaminan Fidusia berada di luar wilayah negara Republik Indonesia, kewajiban sebagaimana dimaksud dalam ayat (1) tetap berlaku.

$X$. Benda yang menjadi obyek jaminan Fidusia adalah benda bergerak baik yang berwujud maupun yang tidak berwujud dan benda tidak bergerak khususnya bangunan yang tidak dapat dibebani hak tanggungan. Benda yang dijadikan jaminan fidusia tetap berada dalam penguasaan Pemberi Fidusia, sebagai agunan bagi pelunasan utang tertentu, yang memberikan kedudukan yang diutamakan kepada Penerima Fidusia terhadap kreditor lainnya. Berlakunya Undang-Undang Jaminan Fidusia di Indonesia secara langsung telah memberikan rasa aman khusunya bagi kreditur dalam kaitannya dengan perjanjian hutang piutang.

XI. Kreditur sebagai penerima fidusia memiliki kewajiban untuk memberitahukan kepada kantor pendaftaran fidusia mengenai hapusnya jaminan fidusia dengan melampirkan pernyataan mengenai hapusnya utang, pelepasan hak, atau musnahnya Benda yang menjadi obyek Jaminan Fidusia tersebut. Salah satu sebab yang mengakibatkan hapusnya jaminan fidusia sebagaimana tersebut diatas adalah karena adanya pembayaran yang melunasi hutang debitur.

XII. Kewajiban kreditur melakukan laporan atas hapusnya hutang kepada kantor pendaftaran fidusia tersebut dalam praktek disebut dengan roya. Roya dilakukan setelah debitur melunasi seluruh hutang yang dimilikinya kepada kreditur. Kewajiban melakukan roya tersebut apabila tidak dilakukan oleh kreditur tentunya akan merugikan debitur karena debitur tidak dapat menjadikan benda yang dimilikinya tersebut sebagai obyek 
jaminan fidusia pada saat debitur akan melakukan perjanjian kredit dengan pihak lain setelah dilunasinya hutang yang lama.

XIII. Meskipun secara hukum dengan adanya pembayaran atas hutang sebagai perjanjian pokok membuat perjanjian jaminan yang bersifat accesoir juga hapus mengikuti perjanjian pokoknya, namun terdapat proses administratif yang harus dilakukan yaitu dengan melaporkan kepada kantor pendaftaran fidusia. Dalam hal ini kelalaian dari kreditur untuk melakukan roya pada jaminan fidusia yang telah dilunasi oleh debitur akan merugikan posisi debitur. Uraian tersebut menggambarkan bahwa debitur harus mendapatkan perlindungan hukum terhadap kelalaian yang dilakukan oleh kreditur. XIV.

\section{B. PERUMUSAN MASALAH} XV.

1) Bagaimana kewajiban kreditur atas jaminan fidusia yang telah dilunasi debitur?

2) Bagaimana tanggung gugat kreditur atas kelalaian melakukan roya pada jaminan fidusia yang telah lunas? XVI.

C. METODE PENELITIAN XVII.

XVIII

Metode

yang digunakan dalam penelitian ini adalah metode penelitian yuridis normatif yang menekankan pada normanorma hukum dengan menganalisa peraturan perundang-undangan terkait. Dalam Penelitian ini peneliti menggunakan dua metode pendekatan masalah yaitu : 1) Statute Approach, pendekatan dengan menelaah semua peraturan perundang-undangan yang bersangkut paut dengan permasalahan (isu hukum) yang sedang dihadapi. 2) Conseptual Approach, yaitu pendekatan yang beranjak dari pandangan- pandangan dan doktrin-doktrin yang berkembang di dalam ilmu hukum. ${ }^{2}$

xIX. PEMBAHASAN

XX.

XXI. Perlindungan Hukum Bagi Debitur Saat Kreditur Tidak Melakukan Roya Atas Jaminan Fidusia Yang Telah Lunas

XXII.

XXIII. Hukum jaminan yang tergolong dalam bidang hukum ekonomi (the economic law), mempunyai fungsi sebagai penunjang kegiatan perekonomian dan kegiatan pembangunan pada umumnya. ${ }^{3}$ Eksistensi perjanjian sebagai salah satu sumber perikatan dapat kita temui landasannya pada ketentuan Pasal 1233 Kitab Undang-Undang Hukum Perdata, yang menyatakan bahwa "Tiap-tiap perikatan dilahirkan, baik karena perjanjian atau karena UndangUndang". ${ }^{4}$

XXIV. Jaminan menurut hukum perdata dapat dibedakan menjadi dua yaitu jaminan perorangan dan jaminan kebendaan, sebagai berikut :

1. Jaminan perorangan (personal guaranty), yaitu jaminan seseorang pihak ketiga yang bertindak untuk menjamin dipenuhinya kewajibankewajiban si debitur. Jaminan ini

\section{Peter Mahmud Marzuki,Penelitian}

Hukum, Kencana Prenada Media, Jakarta, 2010, hal. 95-97

3 Sri Soedewi Maschoen Sofwan, Hukum Jaminan di Indonesia, Pokok-Pokok Hukum Jaminan dan Jaminan Perorangan, Liberty,Yogyakarta, 1980, hal.33

4 Kartini Muljadi dan Gunawan Widjaja, Perikatan Yang Lahir Dari Perjanjian, Raja Grafindo Persada, Jakarta, 2004, hal.1. 
dapat dilakukan tanpa sepengetahuan si debitur.

2. Jaminan kebendaan (persoonlijke en zekelijke zekerheid), yaitu jaminan yang dilakukan oleh kreditur dengan debiturnya, ataupun antara kreditur dengan seseorang pihak ketiga yang menjamin dipenuhinya kewajibankewajiban si debitur. ${ }^{5}$

$\begin{array}{ccc}\text { xxv. } & \text { Berkaitan } & \text { dengan } \\ \text { jaminan } & \text { perorangan, } & \text { Subekti }\end{array}$
berpendapat bahwa jaminan perorangan adalah selalu suatu perjanjian antara seorang berpiutang (kreditur) dengan seorang ketiga, yang menjamin dipenuhinya kewajiban si berhutang (debitur). Ia bahkan dapat diadakan diluar (tanpa) pengetahuan si berhutang tersebut. ${ }^{6}$ Lebih lanjut menurut Subekti, pemberiaan jaminan kebendaan kepada kreditur, memberikan suatu keistimewaan baginya terhadap kreditur lainnya.

XXVI. Dalam praktek jaminan kebendaan diadakan suatu pemisahan bagian dari kekayaan seseorang (pemberi jaminan) yaitu melepaskan sebagaian kekuasaan atas sebagaian kekayaan tersebut dan semuanya itu diperuntukkan guna memenuhi kewajiban debitur bila diperlukan. Kekayaan tersebut dapat berupa kekayaan debitur itu sendiri, ataupun kekayaan pihak ketiga.

XXVII. Pada jaminan kebendaan selalu diikuti dengan adanya pencatatan dan publikasi sebagai pemenuhan asas publisitas. Pencatatan dan publikasi pada hukum kebendaan pelaksanaannya

5 Muhamad Djumhana, Hukum Perbankan Di Indonesia, Citra Aditya Bakti, Bandung, 1996, hal. 248.

6 Subekti dalam Johannes Ibrahim, Cross Default \& Cross Collateral Sebagai Upaya Penyelesaian Kredit Bermasalah, Refika Aditama, Bandung, 2004, hal.79. diserahkan sepenuhnya pada kehendak para pihak yang melangsungkan perbuatan hukumnya. Publikasi ini karena memang ditujukan untuk melindungi kepentingan pihak ketiga adalah terbuka untuk umum. Tidak dilakukannya pencatatan dan publikasi, berakibat tidak berlakunya perbuatan hukum yang dikehendaki oleh para pihak terhadap pihak ketiga, berarti bahwa apabila pencatatan dan publikasi tersebut diabaikan, para pihak tidak dapat mendalilkan hubungan hukum yang ada di antara para pihak terhadap pihak ketiga. $^{7}$

XXVIII. Kewajiban pencatatan dan publikasi atas suatu perjanjian penjaminan yang merupakan perjanjian assesoir dari suatu perjanjian pokok yang bersifat perorangan lahirlah suatu hak kebendaan yang bersifat droit de suite dan droit de preference. Pemegang hak atas jaminan kebendaan yang dijaminkan secara kebendaan tersebut yaitu hak yang melekat atas kebendaan yang dijaminkan kemanapun kebendaan tersebut dialihkan. ${ }^{8}$

XXIX. Salah satu lembaga jaminan yang dikenal dalam sistem hukum jaminan di Indonesia adalah lembaga jaminan fidusia. Fidusia yang berarti penyerahan hak milik atas dasar kepercayaan memberikan kedudukan kepada debitur untuk tetap menguasai barang jaminan, walaupun hanya sebagai peminjam pakai untuk

7 Ida Ayu Made Widyari, “Akibat Hukum Pendaftaran Jaminan Fidusia Dalam Sistem Online", Tesis, Program Pasca Sarjana, Universitas Udayana, Denpasar, 2015, hal. 26

8 Herlien Budiono, Kumpulan Tulisan Hukum Perdata di Bidang Kenotariatan, Citra Aditya Bakti, Bandung, 2008, hal. 230. 
sementara waktu atau tidak lagi sebagai pemilik.

XXX. Jaminan fidusia telah digunakan di Indonesia sejak zaman penjajahan Belanda sebagai suatu bentuk jaminan yang lahir dari yurisprudensi, yang semula berasal dari zaman Romawi. Jaminan Fidusia, selain merupakan bentuk jaminan juga merupakan lembaga titipan. Dalam hukum Romawi lembaga ini dikenal dengan nama fiducia cum creditore contracta yang berarti janji kepercayaan yang dibuat oleh kreditor. Isi janji yang dibuat oleh kreditor dengan debitur adalah bahwa debitur akan mengalihkan kepemilikan atas suatu benda sebagai jaminan utang dengan kesepakatan bahwa debitur tetap menguasai secara fisik benda tersebut dan kreditur akan mengalihkan kembali kepemilikan tersebut kepada debitur bilamana utangnya sudah dibayar lunas. Dengan demikian berbeda dari pignus (gadai) yang mengharuskan penyerahan secara fisik benda yang digadaikan. Dalam hal fiducia cum creditore pemberi fidusia tetap menguasai benda yang menjadi objek fidusia, dengan tetap menguasai benda tersebut, pemberi fidusia dapat menggunakan benda dimaksudkan dalam menjalankan usahanya. $^{9}$ Keduanya timbul dari perjanjian yang disebut pacium fiduciae yang kemudian diikuti dengan penyerahan hak atau in iure cession. ${ }^{10}$

XXXI. Krisis dalam bidang hukum jaminan pada pertengahan sampai dengan akhir abad 19,

9 Rachmadi Usman, Aspek-Aspek Hukum Perbankan Di Indonesia, Gramedia Pustaka Utama, Jakarta, 2001, hal. 282.

10 Henny Tanuwidjaja, Pranata Hukum Jaminan Utang \& Sejarah Lembaga Hukum Notariat, Refika Aditama, Bandung, 2012, hal. 51. mengakibatkan pertentangan berbagai kepentingan, yang ditandai dengan permasalahan yang dihadapi oleh perusahaan-perusahaan pertanian yang melanda negara Belanda bahkan seluruh negara di Eropa. Krisis tersebut melahirkan lembaga jaminan fidusia yang keberadaannya didasarkan pada yurisprudensi. Untuk mengatasi masalah itu lahirlah peraturan tentang ikatan panen atau Oogstverband (Staatsblad 1886 Nomor 57). Peraturan ini mengatur mengenai peminjaman uang, yang diberikan dengan jaminan panen yang akan diperoleh dari suatu perkebunan. Dengan adanya peraturan ini maka dimungkinkan untuk mengadakan jaminan atas barangbarang bergerak, atau setidak-tidaknya kemudian menjadi barang bergerak, sedangkan barang-barang itu tetap berada dalam kekuasaan debitor. ${ }^{11}$

XXXII. Berkaitan dengan berlakunya UU Jaminan Fidusia di Indonesia, Salim HS berpendapat bahwa Undang-Undang Jaminan Fidusia berlaku terhadap setiap perjanjian yang bertujuan untuk membebani Benda dengan Jaminan Fidusia,terutama bagi Lembaga Pembiayaan (Leasing). Jaminan Fidusia adalah hak jaminan atas benda bergerak baik yang berwujud maupun yang tidak berwujud dan benda tidak bergerak khususnya bangunan yang tidak dapat dibebani hak tanggungan sebagaimana dimaksud dalam Undang-Undang No. 4 Tahun 1996 tentang Hak Tanggungan yang tetap berada dalam penguasaan Pemberi Fidusia, sebagai agunan bagi pelunasan uang tertentu, yang memberikan kedudukan yang diutamakan kepada Penerima Fidusia terhadap kreditur lainnya. Jaminan fidusia sendiri sebagaimana yang dipaparkan para ahli adalah perluasan

11 Ibid, hal 154 
akibat banyak kekurangannya lembaga gadai (pand) dalam memenuhi kebutuhan masyarakat dan tidak dapat mengikuti perkembangan di masyarakat. ${ }^{12}$

XXXIII. Berlakunya UU Jaminan Fidusia, maka objek jaminan fidusia diberikan pengertian yang luas. Berdasarkan undang-undang ini, objek jaminan fidusia dibagi dua (2) macam, yaitu:

1. Benda bergerak, baik yang berwujud maupun tidak berwujud; dan

2. Benda tidak bergerak, khususnya bangunan yang tidak dibebani hak tanggungan. ${ }^{13}$

XXXIV. Subjek dari jaminan fidusia adalah pemberi dan penerima fidusia. Pemberi fidusia adalah orang perorangan atau korporasi pemilik benda yang menjadi objek jaminan fidusia sedangkan penerima fidusia adalah orang perorangan atau korporasi yang mempunyai piutang yang pembayarannya dijamin dengan jaminan fidusia.

XXXV. Adapun sifat dari jaminan fidusia berdasarkan Pasal 4 UU Jaminan Fidusia, jaminan fidusia merupakan perjanjian ikutan (accessoir) dari suatu perjanjian pokok yang menimbulkan kewajiban bagi para pihak di dalam memenuhi suatu prestasi untuk memberikan suatu atau tidak berbuat sesuatu yang dapat dinilai dengan uang sehingga akibatnya jaminan fidusia hapus demi hukum apabila perjanjian pokok yang dijamin dengan fidusia hapus.

XXXVI. Sebagai suatu perjanjian accessoir, perjanjian fidusia memiliki sifat sebagai berikut:

12 Salim HS, Perkembangan Hukum Jaminan Di Indonesia, Raja Grafindo Persada, Jakarta, 2004, hal. 57

$13 \mathrm{Ibid}$, hal. 64. a. Sifat ketergantungan terhadap perjanjian pokok

b. Keabsahannya semata-mata ditentukan oleh sah tidaknya perjanjian pokok.

c. Sebagai perjanjian bersyarat, maka hanya dapat dilaksanakan jika ketentuan yang disyaratkan dalam perjanjian pokok telah atau tidak dipenuhi. ${ }^{14}$

XXXVII. Sifat accessoir dari jaminan fidusia ini membawa akibat hukum, bahwa:

a. Dengan sendirinya jaminan fidusia menjadi hapus karena hukum, apabilaperjanjian pokoknya itu berakhir atau karena sebab lainnya yang menyebabkan perjanjian pokoknya menjadi hapus.

b. Fidusia yang menjaminnya karena hukum beralih pula kepada penerima fidusia yang baru dengan dialihkannya perjanjian pokoknya kepada pihak lain.

c. Fidusia merupakan bagian tidak terpisahkan dari atau selalu melekat pada perjanjian pokoknya, karena itu hapusnya fidusia tidak menyebabkan hapusnya perjanjian pokoknya.

XXXVIII.

XXXIX. Karena perjanjian

fidusianya merupakan perjanjian yang bersifat accessoir, sesuai dengan sifatnya tersebut, perjanjian pemberian jaminan fidusia merupakan suatau perjanjian bersyarat, dengan syarat pembatalan sebagaimana diatur dalam Pasal 1253 Jo Pasal 1265 KUHperdata, dengan konsekuensinya, pemberian jaminan fidusia itu dengan sendirinya berakhir atau hapus, kalau perjanjian pokoknya untuk mana diberikan

14 Gunawan Widjaja, Jaminan Fidusia, Raja Grafindo Persada, Jakarta, 2004, hal. 125 
jaminan fidusia hapus, antara lain karena pelunasan. ${ }^{15}$

XL. UU Jaminan Fidusia menganut prinsip pendaftaran jaminan fidusia, sekalipun dalam Pasal $11 \mathrm{UU}$ Jaminan Fidusia disebutkan bahwa yang didaftar tersebut adalah benda yang dibebani jaminan fidusia akan tetapi harus diartikan jaminan fidusia tersebut yang didaftarkan. ${ }^{16}$ Tujuan pendaftaran dimaksudkan untuk memenuhi asas publisitas dengan maksud masyarakat dapat mengakses informasi dan mengetahui adanya dan keadaan benda yang merupakan objek fidusia juga untuk memberikan kepastian terhadap kreditur lainnya mengenai benda yang telah dibebani dengan jaminan fidusia, hal ini mencegah terjadinya fidusia ulang sebagaimana yang dilarang oleh Pasal 17 UU Jaminan Fidusia. ${ }^{17}$

XLI. Kewajiban pendaftaran ini tentu bukan tanpa alasan. Menurut Pasal 37 ayat (3) UU Jaminan Fidusia, jika dalam jangka waktu dimaksud tidak dilakukan penyesuaian, maka perjanjian jaminan fidusia tersebut bukan merupakan hak agunan atas kebendaan sebagaimana dimaksud dalam undangundang ini. Berdasarkan ketentuan ayat ini, maka

XLII. perjanjian jaminan fidusia yang tidak didaftarkan tidak mempunyai hak yang didahulukan (preferen) baik di dalam maupun diluar kepailitan dan atau likuidasi.

15 J. Satrio, Hukum Jaminan : Hak Jaminan Kebendaan, Citra Aditya Bakti, Bandung, 2002, hal. 97

16 Ibid, hal. 175

17 Oey Hoey Tiong, Fidusia Sebagai Jaminan Unsur-Unsur Perikatan, Ghalia Indonesia, Jakarta, 1983, hal. 5
XLIII. Adapun pendaftaran benda yang dibebani dengan jaminan fidusia dilaksanakan di tempat kedudukan pemberi fidusia dan pendaftarannya mencakup benda, baik yang berada didalam maupun diluar wilayah negara Republik Indonesia untuk memenuhi asas publisitas, sekaligus menjamin kepastian terhadap kreditur lainnya mengenai benda yang telah dibebani jaminan fidusia. Pendaftaran Jaminan fidusia dilakukan pada kantor pendaftaran fidusia. Kantor pendaftaran fidusia mencatat jaminan fidusia dalam buku daftar fidusia pada tanggal yang sama dengan tanggal penerimaan pendaftaran. Ketentuan ini dimaksudkan agar kantor pendaftaran fidusia tidak melakukan penilaian terhadap kebenaran yang dicantumkan dalam pernyataan pendaftaran jaminan fidusia, akan tetapi hanya melakukan pengecekan data yang tercantum dalam akta jaminan fidusia.

XLIV. Prosedur selanjutnya, sebagaimana disebutkan dalam Pasal 14 ayat (1) UU Jaminan Fidusia, kantor pendaftaran fidusia menerbitkan dan menyerahkan kepada penerima fidusia sertifikat jaminan fidusia pada tanggal yang sama dengan tanggal penerimaan permohonan pendaftaran. Sertifikat jaminan fidusia yang merupakan salinan dari buku daftar fidusia memuat catatan tentang hal-hal sebagaimana dimaksud dalam Pasal 13 ayat (2) UU Jaminan Fidusia. Jaminan fidusia lahir pada tanggal yang sama dengan tanggal dicatatnya jaminan fidusia dalam buku daftar fidusia.

XLV. Sistem administrasi pendaftaran jaminan fidusia berupa prosedur pendaftaran jaminan fidusia serta penerbitan sertifikat jaminan fidusia yang dapat dilakukan secara online oleh pemohon pendaftaran jaminan fidusia melalui sistem elektronik milik Direktorat Jendral 
Administrasi Hukum Umum (Ditjen AHU). Sumber hukum yang menjadi dasar pembentukkan dan pemberlakuan sistem ini adalah Peraturan Pemerintan Nomor 21 Tahun 2015 Tentang Tata Cara Pendaftaran Jaminan Fidusia Dan Biaya Pembuatan Akta Jaminan Fidusia (selanjutnya ditulis PP No. 21 Th. 2015).

XLVI. Menurut Pasal 25 ayat (1) UU Jaminan Fidusia apabila terjadi hal-hal tertentu, maka Jaminan fidusia demi hukum dianggap telah hapus, kejadian-kejadian tersebut adalah:

1. Hapusnya hutang yang dijamin oleh jaminan fidusia.

2. Pelepasan hak atas Jaminan fidusia oleh penerima fidusia.

3. Musnahnya benda yang menjadi jaminan fidusia.

XLVII. Hapusnya jaminan

fidusia karena lunasnya hutang yang dijamin dengan jaminan fidusia adalah konsekuensi logis dari karakter perjanjian assessoir. Jadi, jika perjanjian hutang piutangnya tersebut hapus karena sebab apapun maka jaminan fidusia tersebut menjadi hapus pula. Sementara itu hapusnya jaminan fidusia karena pelepasan hak atas jaminan Fidusia oleh penerima jaminan fidusia adalah wajar karena sebagai pihak yang mempunyai hak dia bebas untuk mempertahankan atau melepaskan haknya tersebut.

XLVIII. Hapusnya jaminan fidusia karena musnahnya barang jaminan fidusia tersebut dapat dibenarkan karena tidak ada manfaat lagi fidusia itu dipertahankan, jika barang objek jaminan fidusia tersebut sudah tidak ada akan tetapi jika ada asuransi maka hal tersebut menjadi hak dari penerima fidusia dan pemberi fidusia tersebut harus membuktikan bahwa musnahnya barang yang menjadi objek jaminan fidusia tersebut adalah diluar dari kesalahannya. ${ }^{18}$

XLIX. Prosedur yang harus ditempuh jika jaminan fidusia tersebut hapus, yakni dengan melakukan pencoretan (Roya) pencatatan jaminan fidusia tersebut di kantor pendaftaran fidusia. Selanjutnya kantor pendaftaran fidusia menerbitkan surat keterangan yang menyatakan bahwa sertifikat jaminan fidusia tersebut tidak berlaku lagi dan dalam hal ini dilakukan pencoretan jaminan fidusia tersebut dari buku daftar fidusia yang ada pada kantor pendaftaran fidusia.

L. Sesuai dengan sifat accesoir dari jaminan fidusia yang berakhirnya mengikuti perjanjian pokok, maka dengan adanya pelunasan dari debitur yang membuat terpenuhinya segala kewajiban dari debitur akan mengakibatkan perjanjian pokok antara debitur dengan kreditur berakhir, sehingga dengan demikian maka perjanjian tambahan yaitu jaminan fidusia juga berakhir pula. ${ }^{19}$ Namun dengan adanya kewajiban administratif untuk melakukan pencoretan jaminan fidusia maka adanya pelunasan dari debitur belum sepenuhnya mengakhiri jaminan fidusia.

LI. Adanya pencoretan pencatatan jaminan fidusia menjadi hak dari debitur setelah memenuhi kewajiban membayar hutangnya kepada kreditur. Disebutkan dalam Pasal 25 ayat (3) UU Jaminan Fidusia bahwa atas hapusnya jaminan fidusia penerima fidusia memberitahukan kepada Kantor

18 Munir Fuady, Jaminan Fidusia, Citra Aditya Bakti, Bandung, 2000, hal. 50 (selanjutnya ditulis Munir Fuady I)

19 Hatta Isnaini Wahyu Utomo, "Hukum Jaminan”, Bahan Ajar, Universitas Yos Sudarso, Surabaya, 2017, hal. 7 
Pendaftaran Fidusia mengenai hapusnya jaminan fidusia dengan melampirkan pernyataan mengenai hapusnya utang. Merujuk pada Pasal 1 angka 6 UU Jaminan Fidusia yang menyatakan bahwa penerima fidusia adalah perseorangan atau korporasi yang mempunyai piutang yang pembayarannya dijamin dengan jaminan fidusia. Maka kewajiban untuk melakukan pencoretan pencatatan jaminan fidusia adalah menjadi kewajiban dari Kreditur.

LII.

LIII. Tanggung Gugat Kreditur Atas Kelalaian Melakukan Roya Pada Jaminan Fidusia Yang Telah Lunas

LIV.

LV. Tanggung Jawab Hukum adalah kesadaran manusia akan tingkah laku atau perbuatan yang disengaja maupun yang tidak disengaja. Tanggung jawab juga berarti berbuat sebagai perwujudan kesadaran akan kewajibannya. Ridwan Halim, mendefinisikan bahwa "tanggung jawab hukum sebagai sesuatu akibat lebih lanjut dari pelaksaan peranan, baik peranan itu merupakan hak dan kewajiban ataupun kekuasaan. Secara umum tanggung jawab hukum diartikan sebagai kewajiban untuk melakukan sesuatu atau berprilaku menurut cara tertentu tidak menyimpang dari peraturan yang telah ada." 20

LVI. Tanggung jawab hukum dalam hukum perdata berupa tanggung jawab seseorang terhadap perbuatan yang melawan hukum. Perbuatan melawan hukum memiliki ruang lingkup yang lebih luas dibandingkan dengan perbuatan pidana. Perbuatan melawan hukum tidak hanya mencakup

20 Khairunnisa, Kedudukan, Peran dan Tanggung Jawab Hukum Direksi, Pasca Sarjana, Medan, 2008, hal. 4 perbuatan yang bertentangan dengan undang-undang pidana saja, akan tetapi jika perbuatan tersebut bertentangan dengan undang-undang lainnya dan bahkan dengan ketentuan-ketentuan hukum yang tidak tertulis. Ketentuan perundang-undangan dari perbuatan melawan hukum bertujuan untuk melindungi dan memberikan ganti rugi kepada pihak yang dirugikan. ${ }^{21}$

LVII. Tanggung jawab dimaksudkan sebagai keterikatan terhadap ketentuan-ketentuan hukum dalam menjalankan tugas dan kewajibannya, dalam pengertian bahwa semua perbuatan dalam menjalankan tugas kewajibannya harus dapat dipertanggungjawabkan secara hukum, termasuk dengan segala konsekuensinya untuk dikenakan sanksi hukum terhadap pelanggaran norma-norma hukum yang mendasarinya. ${ }^{22}$

LVIII. Istilah tanggung gugat, menurut Agus Yudha Hernoko ${ }^{23}$, tanggung gugat adalah suatu rangkaian untuk menanggung kerugian yang diakibatkan karena kesalahan atau resiko. Hal tersebut juga dijelaskan oleh Y. Sogar Simamora, ${ }^{24}$ bahwa tanggung gugat tidak hanya berupa ganti

21 Komariah, Edisi Revisi Hukum

Perdata,Universitas Muhammadiyah

Malang, Malang, 2001, hal. 12

22 Ghansham Anand, "Karakteristik Jabatan Notaris Di Indonesia Dan Batas Tanggung Gugatnya", Disertasi, Program Studi Doktor Ilmu Hukum, Fakultas Hukum Universitas Airlangga, Surabaya, 2013

23 Agus Yudha Hernoko, kuliah Teori-Teori Tanggung Jawab Hukum dan Tanggung Gugat, tanggal 25 Oktober 2010, Program Studi Doktor Ilmu Hukum, Fakultas Hukum Universitas Airlangga dalam Ghansham Anand, Ibid 
kerugian, namun juga berupa pemulihan kepada keadaan semula. Lebih lanjut, Y. Sogar Simamora menyatakan, inti dari suatu perbuatan melanggar hukum (onrecht-matige daad), yaitu tidak ada hubungan kontraktual antara satu pihak dengan pihak lainnya. Perbuatan melanggar hukum dapat terjadi bila salah satu pihak merugikan pihak lain dengan suatu kesengajaan ataupun ketidaksengajaan dan menimbulkan kerugian pada salah satu pihak.

LIX. Menurut J.

$\mathrm{H}$.

Nieuwenhuis, ${ }^{25}$ tanggung gugat timbul karena adanya perbuatan melanggar hukum (onrehtmatige daad) dan merupakan penyebab (oor-zaak) timbulnya kerugian sedangkan pelakunya bersalah (schuld) maka orang itu harus bertanggung gugat atas kerugian tersebut. Hal ini juga selaras dengan pendapat Marthalena Pohan, yang menyatakan suatu tanggung gugat karena ada suatu kunstfout.

LX. Menurut Peter Mahmud Marzuki ${ }^{26}$ Tanggung gugat (liability/aansprakelijkheid) merupakan bentuk spesifik dari tanggung jawab. Pengertian tanggung gugat merujuk kepada posisi seseorang atau badan hukum yang dipandang harus membayar suatu bentuk kompensasi atau ganti rugi setelah adanya peristiwa

24 Yohanes Sogar Simamora, Kuliah Perbandingan Hukum Perdata, tanggal 26 Oktober 2010, Program Studi Doktor Ilmu Hukum, Fakultas Hukum Universitas Airlangga, dalam Ghansham Anand, Ibid

25 J. H. Nieuwenhuis, Hoofdstukken Verbintenissenrecht, Terjemahan Djasadin Saragih, Surabaya, 1985, hal. 118.

26 Peter Mahmud Marzuki, Pengantar Ilmu Hukum, Prenada Media Grup, Jakarta, 2008, hal. 258-259. hukum atau tindakan hukum. Ia, misalnya harus membayar ganti kerugian kepada orang atau badan hukum lain karena telah melakukan perbuatan melanggar hukum (onrechtmatige daad) sehingga menimbulkan kerugian bagi orang atau badan hukum lain tersebut. Istilah tanggung gugat berada dalam lingkup hukum privat".

LXI. Munir $\quad$ Fuady $^{27}$ menyatakan, teori aansprakelijkheid atau dalam bahasa Indonesia dapat disebut dengan teori tanggung gugat adalah teori untuk menentukan siapa yang harus menerima gugatan atau siapa yang harus digugat karena adanya suatu perbuatan melawan hukum. Jadi tanggung gugat terhadap notaris timbul karena adanya kesalahan yang dilakukan di dalam menajalankan tugas jabatan dan kesalahan itu menim-bulkan kerugian terhadap penghadap atau orang lain. Dapat dikatakan secara sedarhana bahwa setiap kewenangan yang sah baik yang bersumber dari undang-undang maupun dari perjanjian, dapat menimbulkan tanggung jawab pada si pelaksana tugas atau kewajiban itu.

LXII. Sedangkan Menurut Rutten $^{28} \quad$ pertanggungan-jawab (verantwoordelijk-heid) adalah merupakan pengertian, yang harus dibedakan tidak saja dari dapat dipersalahkan (toerekenbaarheid), melainkan juga harus dibedakan dari tanggung gugat (aansprakelijkheid). Tanggung gugat (aansprakelijkheid) merupakan kewajiban hukum (rechtsplicht) untuk memberi ganti kerugian, akan tetapi pertanggungjawab merupakan syarat untuk

27 Munir Fuady, Perbuatan Melawan Hukum, Citra Aditya Bakti, Bandung, 2002, hal. 10. (selanjutnya ditulis Munir Fuady II) 
pertanggung-gugat yang harus ada pada sebelumnya. Orang harus bertanggungjawab menurut undangundang bilamana dan segera ia menurut hukum harus bertanggungjawab atas kerugian yang ditimbulkannya. Maka, pertanggung-jawab di muka pengadilan merupakan dasar umum untuk pertanggung-gugat atas perbuatannya sendiri dan juga orang lain yang melawan hukum serta tindak-tanduk yang tidak me-lawan hukum."

LXIII. Akibat kelalaian yang dilakukan oleh kreditur pihak yang dirugikan dapat menuntut ganti kerugian kepada notaris, apabila memenuhi unsur-unsur sebagai berikut: 29

1. Adanya suatu perbuatan, yaitu suatu perbuatan melawan hukum selalu diawali oleh suatu perbuatan dari si pelakunya.

2. Perbuatan tersebut melawan hukum, yaitu unsur melawan hukum ini diartikan dalam arti seluas-luasnya, yakni meliputi hal-hal sebagai berikut:

a. perbuatan yang melanggar undang-undang yang berlaku,

b. yang melanggar hak orang lain yang dijamin oleh hukum,

c. perbuatan yang bertentangan dengan kewajiban hukum si pelaku,

d. perbuatan yang bertentangan dengan kesusilaan,

e. dengan kehati-hatian atau keharusan dalam pergaulan masyarakat yang baik.

3. Adanya kesalahan dari pihak pelaku, yaitu suatu tindakan dianggap oleh hukum mengandung unsur kesalahan jika memenuhi unsur-unsur sebagai berikut:

a. ada unsur kesengajaan,

b. ada unsur kelalaian,

29 Munir Fuady II, Op. Cit., hal. 10. c. tidak ada alasan pembenar atau alasan pemaaf, seperti keadaan memaksa (overmacht), membela diri, tidak waras, dan lain-lain.

4. Adanya kerugian bagi korban, yaitu kerugian karena perbuatan melawan hukum meliputi kerugian materiil dan immaterial, yang juga dinilai dengan uang.

5. Adanya hubungan kausalitas, yaitu hubungan sebab akibat yang dengan adanya perbuatan yang dilakukan seseorang dapat mengakibatkan pihak lain men-derita kerugian. Ada 2 (dua) teori, yaitu:

a. Conditio Sine Qua Non.

LXIV. Menurut teori ini, setiap orang yang melakukan perbuatan me-langgar hukum selalu bertanggung gugat, jika perbuatannya condition sine qua non menimbulkan keru-gian.

b. Adequate Veroorzaking LXV. Menurut teori ini, si pelaku hanya bertanggung gugat atas kerugian yang merupakan akibat daripada perbuatan melanggar hukum yang secara layak dapat diperkirakan timbul.

LXVI. Sebagaimana telah disebutkan dalam Pasal 25 ayat (3) UU Jaminan Fidusia bahwa kewajiban untuk melakukan pencoretan jaminan fidusia ada pada kreditur dan ketentuan tersebut juga ditegaskan kembali dalam Pasal 16 ayat (2) PP No. 21 Th. 2015 yang menyatakan "Dalam hal Jaminan Fidusia hapus sebagaimana dimaksud pada ayat (1) maka Penerima Fidusia, kuasa atau wakilnya, wajib memberitahukan kepada Menteri dalam jangka waktu paling lama 14 (empat belas) hari terhitung sejak tanggal hapusnya Jaminan Fidusia."

LXVII. Selanjutnya ditegaskan dalam Pasal 17 ayat (2) PP No. 21 Th. 2015 bahwa jika Penerima Fidusia, kuasa atau wakilnya tidak 
memberitahukan penghapusan Jaminan Fidusia maka Jaminan Fidusia yang bersangkutan tidak dapat didaftarkan kembali. Adanya ketentuan tersebut dapat mengakibatkan kerugian bagi pihak debitur terlebih apabila dengan adanya pelunasan tersebut debitur berkeinginan untuk menjaminkan kembali bendanya.

LXVIII. Kreditur pada saat tidak melakukan pencoretan pencatatan Jaminan Fidusia setelah hutang dari debitur dilunasi adalah bertentangan dengan kewajiban hukum dari kreditur sebagaimana ditentukan dalam Pasal 25 ayat (3) UU Jaminan Fidusia jo. Pasal 16 ayat (2) PP No. 21 Th. 2015, baik hal tersebut dilakukan karena kesengajaan ataupun karena kelalaian kreditur. Adanya kewajiban hukum dari kreditur dan adanya kerugian yang dialami oleh kreditur menjadi suatu hubungan kausalitas sehingga dengan kondisi tersebut debitur dapat mengajukan gugatan Perbuatan Melawan Hukum kepada kreditur.

LXIX. Berdasarkan ketentuan Pasal 1365 Kitab Undang-Undang Hukum Perdata disebutkan bahwa Tiap perbuatan yang melanggar hukum dan membawa kerugian kepada orang lain, mewajibkan orang yang menimbulkan kerugian itu karena kesalahannya untuk menggantikan kerugian tersebut. Sehingga dengan demikian kreditur yang dinyatakan bersalah karena kelalaiannya melakukan pencoretan pencatatan Jaminan Fidusia bertanggung gugat untuk mengganti kerugian yang dialami oleh debitur.

LXX.

LXXI. KESIMPULAN

\section{LXXII.}

LXXIII. Jaminan

merupakan perjanjian tambahan (accesoir) yang keberadaannya mengikuti perjanjian pokoknya. Dengan adanya pelunasan hutang yang menjadi perjanjian pokok maka mengakibatkan Jaminan Fidusia menjadi hapus. Pencoretan pencatatan Jaminan Fidusia setelah hapusnya Jaminan Fidusia karena adanya pelunasan hutang oleh debitur menjadi kewajiban dari kreditur. Kreditur yang karena kelalaiannya tidak melakukan pencoretan pencatatan Jaminan Fidusia dalam waktu 14 (empat belas) haris setelah adanya pelunasan hutang dari debitur dapat dikualifikasikan melakukan perbuatan melawan hukum dan bertanggung gugat untuk mengganti kerugian yang dialami oleh debitur jika debitur tidak dapat mendaftarkan kembali jaminan fidusia tersebut.

\section{LXXIV.}

\section{LXXV.DAFTAR PUSTAKA}

LXXVI.

LXXVII. Buku

LXXVIII.

LXXIX. Budiono, Herlien, Kumpulan Tulisan Hukum Perdata di Bidang Kenotariatan, Citra Aditya Bakti, Bandung, 2008

LXXX. Fuady, Munir, Jaminan Fidusia, Citra Aditya Bakti, Bandung, 2000

LXXXI. ---, Perbuatan Melawan Hukum, Citra Aditya Bakti, Bandung, 2002

LXXXII. HS, Salim, Perkembangan Hukum Jaminan Di Indonesia, Raja Grafindo Persada, Jakarta, 2004

LXXXIII. Ibrahim, Johannes, Cross

Default \& Cross Collateral Sebagai Upaya Penyelesaian Kredit Bermasalah, Refika Aditama, Bandung, 2004

LXXXIV. Kamelo, H. Tan, Hukum Jaminan Fidusia Suatu Kebutuhan Yang Didambakan, Alumni, Bandung, 2006

LXXXV. Khairunnisa, Kedudukan, Peran dan Tanggung 
Jawab Hukum Direksi, Pasca Sarjana, Medan, 2008

LXXXVI. Komariah, Edisi Revisi Hukum Perdata,Universitas Muhammadiyah Malang, Malang, 2001

LXXXVII. Marzuki, Peter Mahmud Pengantar Ilmu Hukum, Prenada Media Grup, Jakarta, 2008

LXXXVIII. ---,Penelitian Hukum, Kencana Prenada Media, Jakarta, 2010

LXXXIX. Muhamad Djumhana, Hukum Perbankan Di Indonesia, Citra Aditya Bakti, Bandung, 1996, hal. 248.

XC. Muljadi, Kartini dan Widjaja, Gunawan, Perikatan Yang Lahir Dari Perjanjian, Raja Grafindo Persada, Jakarta, 2004

XCI. Satrio, J., Hukum Jaminan : Hak Jaminan Kebendaan, Citra Aditya Bakti, Bandung, 2002

XCII.Sofwan, Sri Soedewi Maschoen, Hukum Jaminan di Indonesia, Pokok-Pokok Hukum Jaminan dan Jaminan Perorangan, Liberty,Yogyakarta, 1980

XCIII. Tanuwidjaja, Henny, Pranata Hukum Jaminan Utang \& Sejarah
Lembaga Hukum Notariat, Refika Aditama, Bandung

XCIV. Tiong, Oey Hoeng, Fidusia Sebagai Jaminan Unsur-Unsur Perikatan, Ghalia Indonesia, Jakarta, 1983

XCV.Usman, Rachmadi, Aspek-Aspek Hukum Perbankan Di Indonesia, Gramedia Pustaka Utama, Jakarta, 2001

XCVI. Widjaja, Gunawan, Jaminan Fidusia, Raja Grafindo Persada, Jakarta, 2004

XCVII.

XCVIII. Karangan Esai dalam Kumpulan Buku

\section{XCIX.}

\section{Karangan}

C. Utomo, Hatta Isnaini Wahyu, "Hukum Jaminan", Bahan Ajar, Universitas Yos Sudarso, Surabaya, 2017

CI. Widyari, Ida Ayu Made, "Akibat Hukum Pendaftaran Jaminan Fidusia Dalam Sistem Online", Tesis, Program Pasca Sarjana, Universitas Udayana, Denpasar, 2015

Cll. 